\title{
Leukoencephalopathy with brain stem and spinal cord involvement-high lactate syndrome
}

INSERM

\section{Source}

INSERM. (1999). Orphanet: an online rare disease and orphan drug data base. Leukoencephalopathy with brain stem and spinal cord involvement-high lactate syndrome. ORPHA:137898

This disease is characterised by progressive cerebellar ataxia with pyramidal and spinal cord dysfunction, associated with distinctive MRI anomalies and increased lactate in the abnormal white matter. 